$R$. lasiotis longer, more appressed (or tending to lie flat on the skin), of a light greyish-brown colour, and somewhat glistening at certain angles of vision. In R. sumatrensis the muzzle anterior to the nasal horn is much broader, and the space between the ears is proportionally much less. Moreover Mr. Sclater states that "the tail of the Malacca animal is shorter and nearly naked; in that from Chittagong it is longer and tufted at the extremity ;" on the contrary, it is conspicuously shorter in R. lasiotis, and even with its tuft does not descend so low as in the other. That of $R$. sumatrensis is correctly represented in Mr. Sclater's figure of the species, in which also the very strongly marked crease behind the shoulders is not at all exaggerated.

\title{
MISCELLANEOUS.
}

Varieties of the Tiara (Galera barbata). By Dr. J. E. Gray, F.R.S. \&c.

THIs animal is generally brown, with a pale head and a large white or yellow blotch on the throat. It has a large distribution in the tropical or subtropical parts of America.

The British Museum has lately received two half-grown specimens, which have the whole head, neck, and front of back between the shoulders pure white; one of the specimens has the chin and middle of the throat grey. These come from Xalapa in Mexico.

Mr. Salvin sent to the Museum a specimen from Costa Rica, which is entirely black, without any pale colour on the head and neck; and there is a young specimen in the Museum which is entirely of a pale whity-brown colour.

On Branchipus and Artemia. By C. Vogr.

At the meeting of the "Société Helvétique des Sciences Naturelles" held at Fribourg in August last, M. Vogt gave a summary of the results of his researches upon these genera. The first species investigated by him was Branchipus diaphanus, found in August 1871 near the summit of the Reculet (Jura), in artificial ponds dug by the herdsmen for the use of their cattle. M. Vogt obtained several hundred individuals of this species, among which the males and females were nearly in equal numbers. When placed in an aquarium they lived there very well at first, and produced a multitude of eggs, from which larvæ issued; but towards the end of September they all perished by degrees. At the approach of cold weather the water was emptied out of the aquarium, leaving only the mud at the bottom, which was completely frozen during the winter. Towards the end of February the aquarium received some new inhabitants, namely about 50 larvæ of Petromyzon, which concealed themselves in the mud. In the month of May of the present year a certain number of larvæ of Branchipus made their appearance, being hatched, no doubt, from eggs which had remained in the mud. M. Vogt succeeded in rearing several generations of them, which enabled him to follow all the phases of their development. Several 
excursions to the Reculet during the present year furnished no results; no traces of Branchipus could be found in that locality.

Wishing to compare Branchipus with an allied genus, M. Vogt applied to Prof. C. Martins of Montpellier, to ask him for some specimens of Artemia salina, a species of Branchiopod which swarms in the salt marshes of the neighbourhood of Cette. M. Martins sent several thousands of these animals, with a supply of the mother liquors in which they live. They arrived at Geneva in good condition, and are living in an aquarium, in which they produce enormous quantities of eggs and larvæ.

M. Vogt exhibited a bottle filled with living Artemice and their larvæ and explained the structure of the adult Branchipus, describing, among other things, a pair of footjaws which had escaped the observation of MM. Joly, Leydig, \&c. He then dwelt upon the form of the larvæ, which in both Artemia and Branchipus exhibit the primitive fundamental type of the Crustacea, to which the name of Nauplius has been given. But although fundamentally the same, the Nauplii of the two genera present considerable differences, those of Branchipus being shorter and more compressed, and those of Artemia more slender and elongated. The lateral compound eyes appear much later in Artemia than in Branchipus.

The first pair of appendages in the Nauplius consists of two antennæ which afterwards become the antennæ of the perfect animal. The second pair forms the chief or sole organ of locomotion of the larva; and after numerous moults these appendages finally become the horn-shaped pieces which serve as prehensile organs in the male Branchipus and are rudimentary in the female. The third pair serve the larva to carry its food to its mouth; in the adult it forms the mandibles, which constitute the third pair of appendages. The eleven pairs of natatory feet and the pair of footjaws of the adult originate subsequently by budding.

M. Vogt confirms the observation of M. Joly that among the Artemice collected at Cette during the months of July and August there are no males, and that the females propagate by parthenogensis. This fact is the more remarkable as we find males in great abundance in other salt marshes inhabited by the same or analogous species.Bibl. Univ. Sept. 15, 1872, Arch. des Sci. p. 30.

\section{On Osteocella septentrionalis from British Columbia.}

By Dr. J. E. Gray, F.R.S. \&c.

The substance described by me in the 'Annals, 1872 , ix. p. 406 , under this name was, at the meeting of the British Association at Brighton, and since in 'Nature,' regarded as the notochord of a fish ! Professor Dawson of M'Gill College, Montreal, Canada, states that it was submitted to Professor Verrill of Yale College, who "had no doubt as to its nature" (that is, of its being the axis of a Virgularia or some similar creature), "but believed it probably belonged to an undescribed species." Dr. Dawson states that Mr. Selwyn's specimen has " attached to the granulated lower extremity some trace of animal matter, in which I think I can detect, under the microscope, a few club-shaped spicules." 


\section{$2 \mathrm{BHL}$ Biodiversity Heritage Library}

Vogt, Karl Christoph. 1872. "On Branchipus and Artemia." The Annals and magazine of natural history; zoology, botany, and geology 10, 405-406. https://doi.org/10.1080/00222937208696722.

View This Item Online: https://www.biodiversitylibrary.org/item/81231

DOI: https://doi.org/10.1080/00222937208696722

Permalink: https://www.biodiversitylibrary.org/partpdf/63347

\section{Holding Institution}

Smithsonian Libraries

\section{Sponsored by}

Smithsonian

\section{Copyright \& Reuse}

Copyright Status: Public domain. The BHL considers that this work is no longer under copyright protection.

This document was created from content at the Biodiversity Heritage Library, the world's largest open access digital library for biodiversity literature and archives. Visit BHL at https://www.biodiversitylibrary.org. 